\title{
WINCKELMANN, LESSING E HERDER: ESTÉTICAS DO EFEITO?
}

Marco Aurélio WERLE ${ }^{1}$

- RESUMO: Este artigo investiga, sob a perspectiva de uma estética do efeito, as origens da assim chamada "estética da época de Goethe", segundo a obra de Lessing, Winckelmann e Herder. Pretende-se mostrar que há nestes autores tanto uma influência do parâmetro do efeito, suscitado pela obra de arte no espectador, quanto o apontamento para uma instância, por assim dizer crítica, idealista e especulativa de apreciação do fenômeno artístico.

- PALAVRAS-CHAVE: Winckelmann; Lessing; Herder; estética.

A arte, e em especial a poesia trágica, foi examinada desde Aristóteles até Lessing segundo o ponto de vista do efeito.

(Szondi, 1974, p.284).

\section{Introdução}

Em termos de originalidade, a reflexão alemã clássica sobre estética pode ser caracterizada por alguns tópicos, dentre os quais estão, por exemplo: 1. visão crítica acerca da história, no que toca a uma consciência da relação entre antigos e modernos; 2. rompimento com uma poética

1 Departamento de Filosofia - Faculdade de Filosofia e Ciências - UNESP - 17525-900 - Marília SP. 
e estética normativas e afirmação de uma reflexão histórica sobre arte, o que resultou, por exemplo, nas filosofias da arte de Hegel e Schelling; 3. rompimento com a noção tradicional acerca dos gêneros. Exemplos disso são a noção de ingênuo e sentimental em Schiller, a noção de romance e dos tipos poéticos em Schlegel e a idéia da contraposição dos tons poéticos em Hölderlin; 4. estabelecimento da autonomia da disciplina de estética (cf. Szondi, 1974). Os principais representantes dessa reflexão são Winckelmann, Lessing e Herder, numa primeira etapa, Kant, Schiller e os românticos A. e F. Schlegel, Novalis, além de Hölderlin e Schelling, numa segunda etapa, e Hegel, numa terceira etapa. A esses pensadores juntam-se poetas, dentre os quais estão o próprio Schiller e o maior representante de sua geração, que é Goethe. Costuma-se mesmo situar o referido período a partir do tempo da atividade poética de Goethe (que se iniciou por volta de 1770 e se estendeu até sua morte em 1832), o que resultou na conhecida expressão "época de Goethe" [Goethezeit]..$^{2}$

Neste artigo, pretende-se abordar um aspecto do momento inicial da estética da época de Goethe, marcado pelos três nomes já citados: Winckelmann, Lessing e Herder. Neles ainda não se encontram desenvolvidos todos os pontos referentes à originalidade da estética da época de Goethe enquanto tal. $\mathrm{E}$ isso não em virtude de uma deficiência, mas simplesmente porque esses pontos não foram todos conquistados de um momento para o outro. Houve uma espécie de progressão na reflexão dessa época que, em certa medida, se confunde com a própria consolidação da cultura e da filosofia alemãs clássicas. Segundo essa perspectiva, pretendo apontar para o aspecto precursor que se encontra nas reflexões de Winckelmann, Lessing e Herder, o que não significa que se deva considerá-los mais ingênuos do que os posteriores; pelo contrário, o que neles sempre surpreende é o frescor em termos de intuições estéticas. Essa vivacidade, como não podia deixar de ser, é marcada por algo que constantemente surpreende, por um elemento transformador e jovem. Por estarem no começo, esses autores ao mesmo tempo avançam como também ficam presos ao que é tradicional. Na ânsia de estabelecer novos fundamentos, suas intuições originárias, depois de afirmadas, são muitas vezes contraditórias com seus próprios pressupostos. $\mathrm{O}$ caso mais flagrante disso é a sugestão de Winckelmann de que os modernos devem imitar os antigos (gregos), depois de ter justamente criticado, em princí-

2 Passarei, a seguir, a empregar o termo estética da época de Goethe para designar a reflexão alemã clássica sobre arte e estética. 
pio, a idéia de imitação. Outras vezes, as intuições desses autores passam despercebidas para eles mesmos ou são mal desenvolvidas (é o caso da noção de história em Herder), ou não são esgotadas, no sentido de não serem exploradas todas as implicações possíveis de uma dada intuição (é o caso do Laocoonte de Lessing).

A posição produtivamente ambígua desses autores na estética da época de Goethe torna-se um pouco mais clara se a examinamos com base na noção de uma estética do efeito (Wirkungsästhetik). ${ }^{3}$ Mediante este termo situam-se aquelas estéticas que buscam afirmar que a obra de arte necessita ser analisada ou compreendida essencialmente em vista de seu efeito [sein wirken]. Esse efeito, no caso desses autores, é em geral assinalado de um ponto de vista psicológico. Busca-se mostrar que a obra de arte deve provocar determinada reação no sujeito ou no público ao qual se destina. Quanto a isso, porém, importa distinguir uma estética do efeito de uma estética que afirma também a importância do efeito, que a obra de arte deve exercer sobre o espectador ou a alma humana, mas não enfatiza este aspecto como o central. Tal é o caso da estética de Hegel, para quem a obra de arte também deve necessariamente levar em conta o público ao qual se destina, mas esse ponto de vista é absorvido em Hegel por outros, num contexto mais amplo de uma reflexão de cunho histórico sobre a arte, de modo que não se pode chamá-la de uma estética do efeito. ${ }^{4}$ Igualmente é preciso notar que os três autores em causa não possuem uma estética do efeito em sentido absoluto, pois tanto se situam nela como dela também se afastam. Mas é por isso mesmo que há interesse em examiná-los à luz desta questão, pois assim podem-se melhor vislumbrar suas posições na estética da época de Goethe: em que medida ainda permanecem presos ao que esta estética supera e em que medida apontam para o futuro, para a instauração de um novo paradigma que, na verdade, os ultrapassa. Em termos do que veio depois, ainda no interior da estética da época de Goethe, pode-se dizer que uma estética do efeito encontra-se também presente em Kant, na Crítica do juizo, mais precisamente na noção de gosto, que guia a análise do belo e do sublime, e em Schiller, no propósito moral inerente à arte. Mas ambos, tal como Hegel, já se encontram num campo diferente, no qual o efeito é absorvido num

3 Essa perspectiva de análise apóia-se, em parte, em Peter Szondi, 1974.

4 Cf. principalmente "A determinidade exterior do ideal" bem como outras passagens do Curso de estética, por exemplo a caracterização da relação do gênero dramático com o público, em que há uma crítica a F. Schlegel e a Ludwig Tieck por desconsiderarem este aspecto (Hegel, 1986, v.13, p.341-60 e v.15, p.497). A paginação da edição Suhrkamp se encontra introduzida por barras verticais na tradução brasileira. 
horizonte de outros aspectos. ${ }^{5}$ Isso porque a partir de Kant começa-se a abordar a estética como esfera autônoma, e passa-se sempre mais a buscar um ponto de apoio imanente para a compreensão da arte, o qual incluirá de modo essencial a idéia de crítica e de historicidade, em que a questão do efeito não mais poderá receber grande destaque ou privilégio. Em termos do passado, do que veio antes de Winckelmann, Lessing e Herder, podemos dizer que a estética do efeito constitui o traço da dependência de uma atmosfera intelectual acostumada a situar a poesia e a arte segundo princípios gerais (o "gosto" ou o "sentimento") ou segundo as "poéticas". ${ }^{6}$ Entretanto, para Winckelmann, Lessing e Herder, que estão no começo de uma nova era, estes pressupostos apresentam-se problemáticos.

No exame a seguir, o procedimento será o seguinte: primeiramente, os autores serão situados, em termos gerais, no ambiente estético e artístico no qual viveram; a seguir, por meio da interpretação de textos representativos, importa verificar como se posicionam em sentido mais amplo na época de Goethe, e isso tendo em vista os vínculos que mantêm com uma estética do efeito e com o pensamento de sua época.

\section{O ambiente pré-romântico}

O que marca o ambiente literário alemão da época pode ser compreendido principalmente a partir do que girava em torno do movimento Tempestade e ímpeto [Sturm und Drang], que eclodiu na Alemanha por

5 Encontramos os primeiros exemplos disso também em Schelling e em F. Schlegel, na reflexão sobre o gênero trágico. O primeiro situa a tragédia, na décima das Cartas filosóficas sobre o dogmatismo e o criticismo, a partir dos conceitos de liberdade e necessidade (destino) (Schelling, 1973, p.208-11) e o segundo, em Sobre o estudo da poesia grega, no conflito entre o entendimento e a força ativa (Schlegel, 1956, p.136). Nas duas perspectivas, opera-se no horizonte de uma filosofia histórica da arte, embora Schlegel não compreenda a sua perspectiva como de "filosofia da arte" (cf. a rejeição deste conceito nos fragmentos críticos 12 e 123 do Liceum, Schlegel, 1997, p.22, p.40).

6 Lavater, em seus Fragmentos fisionômicos (1775), relaciona com freqüência o gênio ao efeito, apontando assim para a presença clara da questão do efeito em sua época (cf. o décimo fragmento em Tempestade e ímpeto. Estudos críticos). Entretanto, a perspectiva do efeito para o estudo dos problemas estéticos do século XVIII foi também defendida por Herbert Dieckmann (1969, p.179), especialista na obra de Diderot. E aqui encontramos também um elo entre o século XVIII e a atualidade, pois esse texto de Dieckmann foi concebido para o ciclo de discussões intitulado Hermenêutica e poética, coordenado por Jauss, defensor de uma estética da recepção (em que o "efeito" é um tema central). 
volta de 1770 e que consistia numa emancipação das letras nacionais. O título vem de uma peça de F. M. Klinger, intitulada justamente Sturm und Drang. Embora pareça uma radicalização do espírito da ilustração, esse movimento constituiu-se como uma luta contra a ilustração, uma luta de jovens espíritos (Hamann, o mago do norte, Herder, Goethe, Lenz e até Schiller), cujos temas básicos eram: a incompatibilidade entre o indivíduo e a sociedade, o que resultava numa dor do mundo (Weltschmerz); a ênfase no gênio criador que se afirma livre das regras artísticas (deve-se dar vazão aos impulsos naturais e vigorosos); o acentuado individualismo nas artes; o sentimentalismo etc. (cf. Autores pré-românticos alemães, 1991, p.7-10). Um traço comum da maior parte desses autores é a linguagem violenta que busca principalmente o exercício da crítica ferrenha. No caso de Schiller, na época bastante jovem, sua inserção no movimento deu-se quando este já estava quase no fim. Sua peça dramática $O s$ bandidos [Die Raüber] de 1781 constitui um de seus ápices, ao proclamar "um grito de liberdade contra este século de injustiças e desumanidade" (segundo Karl Moor, reunido com seus companheiros às margens do Danúbio, floresta da Boêmia, fugindo e se opondo à sociedade) (Schiller, 1992, p.105). Goethe, um pouco mais velho do que Schiller, foi, entretanto, quem escreveu as principais obras do movimento: o romance Os sofrimentos do jovem Werther, de 1774, e o Götz von Berlichingen, um drama (Schauspiel), surgido um ano antes. Em termos da história da estética, esse movimento incorpora a postura alemã da época diante da literatura e da poesia, postura que pode ser pensada levando-se em conta os seguintes traços: 1. referência à Idade Média (o que também será usual junto aos românticos); 2. crítica a Aristóteles em vista do pouco espaço dado aos caracteres no drama; ${ }^{7} 3$. redescoberta, entre os antigos, de Homero e, entre os modernos, de Shakespeare; 4. valorização da figura do gênio (influência inglesa) e do princípio da natureza (Rousseau).

Essas tendências no pensamento alemão da época podem ser averiguadas de modo exemplar dando-se uma olhada no drama Götz von Berlichingen, de Goethe. O personagem central é o próprio Götz, um cavaleiro da baixa Idade Média que luta ao lado dos camponeses pela liberdade destes. Todo o drama está centrado nele, ele que é o herói virtuoso e fiel ao rei, mas opositor dos príncipes que exploram o povo. A estrutura das cenas não segue a lei da unidade de Aristóteles, a qual era muito enfati-

\footnotetext{
7 Um dos autores do movimento que acentuaram esse tópico foi Lenz. Cf. Anotações sobre teatro (Sturm und Drang, 1949, p.725-7).
} 
zada pelo classicismo francês, pois estão todas amarradas pelo caráter do herói, e as inúmeras cenas paralelas sempre a ele devem ser referidas. Tal é o caso, por exemplo, daquelas que retratam a infeliz relação amorosa entre Weislingen, também cavaleiro, inicialmente amigo de Götz, depois inimigo, e a irmã deste, Maria. ${ }^{8}$ Essa trama não tem uma relação direta, em termos da ação principal, com o conflito básico da peça, que é o de Adelheid, representante dos príncipes, com Götz, representante do povo. Do mesmo modo, as cenas que envolvem o triângulo amoroso entre Adelheid, Franz e Weislingen, no ambiente da corte, são bastante independentes, em termos do todo da unidade de ação. Essa estrutura dramática é certamente copiada dos dramas shakespeareanos, que também enfatizam o caráter do herói e não seguem o modelo preconizado pelo classicismo francês. A presença de um drama não tão fechado aponta também para uma nova valorização ou, se quisermos, para uma relativização do gênero. Aos poucos começa-se a não mais ver os antigos unicamente por meio do drama, mas por outros gêneros, como a épica, por exemplo, e daí a possibilidade da emergência de Homero. A própria referência a Shakespeare não tem em vista homenagear a tragédia, o gênero enquanto tal. Poderíamos mesmo dizer que o Götz é um drama que incorpora elementos épicos, embora sua extensão não seja longa, já que segue o modelo das tragédias modernas de cinco atos. No entanto, certas situações são perfeitamente épicas, como os diferentes confrontos bélicos. Essas cenas de violência e de exageros físicos (o próprio Götz é uma figura até certo ponto grotesca, evidenciada por sua "mão de ferro" - o título completo da peça é Götz von Berlichingen mit der eisernen Hand; Cf. Goethe, 1947) mostram também a intenção de ressaltar caracteres e situações naturais. E aqui está a presença de Rousseau: é preciso refletir a sociedade tal como ela é naturalmente (Götz e os camponeses) e é preciso mostrá-la agindo do modo o mais natural possível (cenas fortes, em que há decapitações e mortes sangrentas), em contraste com o artificialismo

8 A figura de Weislingen também inspirou Goethe na constituição do personagem Clavigo, da peça Clavigo de 1776, como nos diz o próprio Goethe numa carta a Schönborn de 1774: "Clavigo ... o pendant de Weislingen no Götz, muito mais Weislingen mesmo em todo o acabamento de um personagem central" (citado em Goetz, 1947, p.73). Com efeito, Clavigo é uma figura indecisa, hipócrita, que teme sobretudo perder sua posição social, mas não consegue livrar-se do sentimento amoroso pela amada que se coloca em seu caminho. Em Clavigo temos, portanto, um conflito entre a aspiração pela felicidade pessoal e a aspiração pelo poder. Note-se que Schopenhauer (1988, p.338, § 51), grande admirador de Goethe, considera essa peça um modelo completo do drama, "que supera em muito outras peças do mesmo grande mestre". 
da vida da corte. Tudo isso indica uma produção de gênio, alguém que não se submete às regras, mas as subverte. ${ }^{9}$

Mas embora o movimento pré-romântico Tempestade e ímpeto constitua o acontecimento literário mais importante de sua época, os três autores que se pretende examinar não tiveram, à exceção de Herder, uma relação direta com ele. Lessing até se lhe opunha, pois considerava seu individualismo um exagero, e Winckelmann nem tomou parte dele, porque morreu alguns anos antes, assassinado por um assaltante em Trieste, em 1768. Mesmo assim, é possível situá-los enquanto autores que caminham junto com esse movimento, no sentido de buscarem novos fundamentos para a arte. Além disso, há muitos pontos em comum, apesar das diferenças. Algumas semelhanças: 1. Em toda essa época, há uma crítica ao classicismo francês, ao domínio da literatura francesa, na medida em que esta encarnava as regras clássicas (Boileau); ${ }^{10}$ 2. Ao lado disso, apresenta-se uma busca pelo verdadeiro sentido dos antigos, sendo este tópico mais forte em Winckelmann, o grande descobridor da Antigüidade clássica, do que em qualquer outro. A estratégia comum era precisamente opor o autêntico Aristóteles (segundo se supunha) ao Aristóteles dos franceses (o modelar). Se bem que essa estratégia não se aplica tanto a Winckelmann, para quem a relação com a Antigüidade grega era mais plástica do que marcada pelos parâmetros da teoria da tragédia; 3 . Junto à defesa do sentido autêntico dos antigos vem a adoração a Shakespeare, bastante forte em Lessing e Herder. Neste caso, além de contrapor o pensador da tragédia antiga, o Aristóteles autêntico, ao classicismo francês, também se lhe opunha a excelência poética moderna. Shakespeare é visto como um poeta que fala a partir da alma e que constrói autênticos caracteres, ao contrário do artificialismo dos personagens do teatro francês. Para Herder, ele era o poeta representante dos povos do norte, alguém que não se atinha às regras poéticas em voga. Ele é o exemplo do gênio, termo usado tanto por Lessing como por Herder para designar o verdadeiro poeta; 4 . Outro ponto comum, mas também de diferença, e que é mais forte em Lessing, é a crítica ao regime absolutista e a defesa de uma cultura alemã própria baseada numa sociedade burguesa. Em

9 Hamann foi um dos autores que mais defenderam a noção de gênio na época, para quem em Homero o gênio substitui as regras de Aristóteles, cf. Considerações socráticas (Sturm und Drang, 1949, p.79); cf. igualmente o texto de Lavater, citado anteriormente.

10 A influência francesa era tal na Alemanha que Frederico II, monarca da Prússia, um grande amante da cultura francesa, optou por um inexpressivo francês em vez de Lessing para dirigir a biblioteca real de Berlim ("Lessing, 1991, p.14). A polêmica de Lessing com Gottsched também se insere nesse contexto. 
Winckelmann temos uma superação da estética inicial da Aufklärung, quando da defesa do princípio da simplicidade e negação do rebuscamento (barroco). No movimento Tempestade e ímpeto há também uma crítica ao absolutismo, mas aí a solução não está na sociedade burguesa, enquanto coletividade, e sim no individualismo. 5 . Nesses pontos comuns, porém, impera um que abrange a todos e que é central para as concepções de arte dos nossos três autores: o que se refere ao início de uma nova consciência histórica.

\title{
Winckelmann: a descoberta da Antigüidade grega
}

\author{
Encontramos Winckelmann junto a um determinado \\ tatear. Mas a grandeza consiste no fato de seu tatear sempre \\ apontar para algo. Ele é parecido com Colombo, quando este \\ ainda não descobrira o novo mundo, mas já o intuía. Não \\ aprendemos nada quando o lemos, mas nos tornamos algo.
}

(Goethe apud Winckelmann, 1946, p.22)

A grande importância de Johann Joachim Winckelmann para a cultura européia ocidental - não só alemã, pois sua obra principal, História da arte da Antigüidade [Geschichte der Kunst des Altertums], de 1764, é um dos principais monumentos de prosa clássica européia - consiste, conforme se sabe, na nova visão que forjou da Antigüidade clássica. Durante toda a sua vida, desde a primeira juventude, dedicou-se ao estudo da poesia e da cultura da Grécia antiga que, na época, era pouco estudada e valorizada. Contra a arte total do barroco, a arte então em voga, Winckelmann privilegiava uma volta ao que é simples, ao que é destituído de pompa. Essa simplicidade de beleza e idealidade nobre ele encontrava justamente na Grécia antiga, principalmente na escultura. E é aqui que está a sua originalidade: ter visto uma Grécia que até então ninguém havia reconhecido desse modo. Pois costumava-se pensar a Grécia com base na idéia de um mundo greco-romano, ou seja, a partir de um mundo grego romanizado. A própria Renascença, que postulou uma volta aos antigos, não conseguia perceber a especificidade dos gregos diante dos romanos. No caso da Alemanha, deve-se lembrar que nem essa idéia dos antigos havia, pois que a reforma luterana impediu que ali 
ocorresse uma Renascença. ${ }^{12}$ Nessa terra dividida entre inúmeros principados e ducados, imperava uma arte absolutista e barroca. ${ }^{13}$ Winckelmann, tal como Lessing, se opõe a esse mundo feudal guiado pela Igreja e pelos príncipes, defendendo uma arte dirigida para os homens, uma arte burguesa, que primasse pelo que é simples e não pelo que é rebuscado e tortuoso.

Para o presente propósito, importa examinar em que consiste mesmo a contribuição específica de Winckelmann para a estética da época de Goethe. Em relação a isso, dois aspectos podem ser destacados em sua obra: o primeiro se refere ao modo como apreende a arte grega; o segundo diz respeito à sugestão que dá aos modernos para que a imitem, posto que seria superior. Em relação ao primeiro aspecto, podemos citar a conhecida expressão de Winckelmann sobre a arte dos gregos: ela se caracterizaria por uma "nobre simplicidade e grandeza serena" (edle Einfalt und stille Grösse) (Winckelmann, 1975, p.53). Essa noção inédita acerca dos gregos, uma vez que na época se via a arte grega como um naturalismo ingênuo, perdurará até o século XIX. Em certa medida, pode-se dizer que a noção em si já estava presente no Renascimento, mas que não era identificada como a especificidade da arte grega. ${ }^{14}$ Identificá-la como algo que somente a Grécia teria desenvolvido com perfeição, esta é a novidade de Winckelmann. ${ }^{15} \mathrm{O}$ segundo aspecto central de sua obra é uma decorrência do primeiro, ou seja, da nova visão que forjou da

12 A questão da ausência de uma Renascença na Alemanha é antiga, tanto que antes mesmo de Lutero ela já se afigurava impossível. Erwin Panofsky, num texto sobre a pintura de Albrecht Dürer, busca mostrar que o mestre da pintura alemã tentava fazer uma apropriação da Antigüidade clássica em oposição aos modelos italianos sem, no entanto, deixar de estudá-los. Com isso, ele se opunha à idéia de uma renascença tal como era concebida na Itália, pois era preciso uma apropriação que se adequasse à especificidade nórdica; para a Itália, extensão do mundo clássico antigo, não havia dificuldades quanto a isso (cf. Panofsky, 1979, p.351).

13 A revolução burguesa aconteceu mais tarde na Alemanha. Por isso, a influência francesa e inglesa, em cujos países já se havia superado o barroco, não foi irrestrita na Alemanha. Por exemplo, a influência dos dramas de Corneille, que enfatizavam a autonomia do herói, não penetrava totalmente no drama alemão. Dessa noção os alemães só retiveram o que lhes convinha: a idéia cristianizada do herói mártir (presente nas obras de Andreas Gryphius). Cf. A idéia do sublime na literatura alemã em Viëtor, 1952, p.243.

14 Na verdade, quem primeiramente lidou de modo mais intenso com a idéia de nobre simplicidade e grandeza serena, depois do Renascimento, foi Boileau, em sua acolhida de Longino. Essa acolhida, no entanto, deu-se no contexto da Querelle des anciens et des modernes, da qual Winckelmann já começa a se afastar (cf. Viëtor, 1952, p.238, 251 e 348).

15 Uma conseqüência importante dessa delimitação e que será desenvolvida não por Winckelmann, mas pelos românticos e idealistas, é a constatação da absoluta diferença entre os antigos e os modernos, pois os antigos seriam "unidos" (harmoniosos) e os modernos "cindidos" (referência à separação entre alma e corpo, sujeito e mundo). 
arte grega, pois Winckelmann não só fornece uma nova interpretação dos gregos, mas uma nova valoração. Ele sustenta que a arte deles seria a maior e melhor já feita por qualquer povo em qualquer época. Desse modo, caberia aos modernos, seus contemporâneos, "uma vez que quisessem ser grandes" (Winckelmann, 1975, p.39), tomar a arte grega como modelo, para tentar se aproximar deles e, assim, fazer uma arte superior e autêntica. Este segundo aspecto da obra de Winckelmann costuma ser rotulado pelo termo "classicismo", com o que se entende que é preciso tomar o clássico como modelo: os gregos originais, o princípio da escultura, especialmente, e não as regras de Aristóteles apenas, tal como eram lidas pelo classicismo francês.

Para esclarecer esses dois aspectos e a interligação entre eles, convém dar uma olhada no texto onde melhor se encontram formulados, as Reflexões sobre a imitação das obras gregas na pintura e na escultura [Gedanken über die Nachahmung der Griechischen Werke in der Malerei und Bildhauerkunst], um dos primeiros escritos de Winckelmann, que data de 1755, quando estava com 38 anos. ${ }^{16}$ Antes de tratar do texto, uma elucidação acerca de como se devem compreender os dois aspectos mencionados: pois não se podem simplesmente tomar algumas afirmações de Winckelmann acerca da arte grega e sacralizá-las como se implicassem a verdade última do que ele realmente pensou. No que toca à idéia de "nobre simplicidade e grandeza serena", por exemplo, é preciso notar que essa frase não "contém" a última palavra de Winckelmann acerca da arte grega. Há que notar que Winckelmann, tal como Hölderlin explorará mais tarde, já intuía uma espécie de tensão na arte grega, ten-

16 A diferença entre esse texto e História da arte da Antigüidade é que no primeiro se afirma a superioridade da arte grega e que no segundo não só se afirma isso como também se explica mais exaustivamente como ela nasce, se desenvolve e desaparece (cf. Mann, 1961, p.95). Na Introdução de História da arte da Antigüidade, lê-se: "Os relatos mais antigos nos ensinam que as primeiras figuras representavam o homem como ele era, não como ele aparecia, representavam seu contorno [Umkreis], não sua aparência [Ansicht]. Da simplicidade da figura partiu-se para a pesquisa das relações, o que permitiu uma certeza e possibilitou, com segurança, a ousadia de uma elevação, através de que a arte chegou à grandeza e, finalmente, entre os gregos, atingiu gradualmente a mais alta beleza. Depois que todas as partes da mais alta beleza estavam unidas e procurou-se seu enfeite [Ausschmückung], penetrou-se na superficialidade, de sorte que a grandeza da arte se perdeu. Finalmente ocorreu a sua completa decadência. Este é, em poucas palavras, o propósito do tratado desta história da arte" (p.25). No entanto, as intuições originais de Winckelmann já se encontram todas em seu estudo sobre a imitação, e na História... ele somente as complementa em termos de referências históricas mais amplas. Note-se também que História da arte da Antigüidade é a primeira obra a trazer no título o termo "história da arte". Não foi Winckelmann, porém, quem criou a disciplina da história da arte e sim Von Rumohr (autor com quem Hegel discute em sua estética a respeito do conceito de ideal), no início do século XIX (Panofsky, 1979, p.413). 
são que não se resolve somente com uma noção unilateral como a de "harmonia". Para tanto, basta refletir sobre a metáfora do mar empregada por Winckelmann para explicar a escultura do Laocoonte. ${ }^{17}$ Diz Winckelmann $(1975$, p.53):

Enfim, o caráter geral, que antes de tudo distingue as obras gregas, é uma nobre simplicidade e uma grandeza serena tanto na atitude como na expressão. Assim como as profundezas do mar permanecem sempre calmas, por mais furiosa que esteja a superfície, da mesma forma a expressão nas figuras dos gregos mostra, mesmo nas maiores paixões, uma alma magnânima e ponderada. ${ }^{18}$

A obra de arte sobre o Laocoonte, para Winckelmann, seria perfeitamente grega, uma vez que os termos "nobre simplicidade e grandeza serena" não se referem à mera superfície. A superfície não é imediatamente reveladora do caráter das obras de arte. Desse modo, a hipótese de uma espécie de tensão na obra de arte grega torna-se plausível, no sentido de que seria possível haver uma aparência reveladora de algo mais profundo. Em outras palavras, haveria de se considerar uma escultura grega que, na superfície, não seguisse o princípio norteador da "nobre simplicidade e grandeza serena". Este exemplo abala a idéia de que esse princípio é um critério completamente exterior, da aparência exterior da obra. ${ }^{19} \mathrm{E}$, assim, também devemos considerar com cautela a questão do classicismo, pois, embora não reste dúvida de que Winckelmann postula uma imitação dos gregos, essa não poderá nunca ser uma mera "macaqueação" ou "cópia". E, sendo o critério de beleza grega algo que se apresenta no íntimo e não na superfície da obra de arte, a própria idéia de imitação, postulada por Winckelmann, torna-se complexa.

A complexidade dessa noção se expressa bem num texto posterior, de 1759, intitulado Advertências sobre a maneira de contemplar obras

17 "Laocoonte, sacerdote de Tróia, que no famoso grupo de mármore se debate, junto com seus dois filhos, contra as serpentes que, à ordem dos deuses, o atacam e matam. A obra, ao que parece esculpida um pouco antes da era cristã e redescoberta em 1506, foi considerada durante longo tempo, erradamente, como obra-prima da fase clássica da arte grega" (Lessing, 1991, p.11).

18 Em relação a essa metáfora, tem-se a impressão de que Gerd Bornheim, ao escrever a introdução à tradução brasileira de Reflexões..., se enganou quanto ao que Winckelmann quis dizer com ela. Na página 26 , ele interpreta que Winckelmann teria considerado a profundidade caótica, quando, como se vê nas próprias palavras citadas, a superfície é que é caótica.

19 Desse ponto de vista, o juízo de Lessing sobre Winckelmann, para quem ele só avalia esta escultura com base no olhar e não na imaginação, não é inteiramente justo. 
de arte [Erinnerung über die Betrachtung der Werke der Kunst], no qual é dito:

Contrária ao pensamento independente é a cópia, não a imitação; por aquela entendo a derivação servil, mas através desta pode o imitado assumir, por assim dizer, se é conduzido numa boa direção, outra natureza e pode chegar a ser algo de original e próprio. (Winckelmann, 1959, p.116)

Guardadas as devidas diferenças, pode-se aproximar esta noção de imitação da de Kant e relacioná-la à diferença entre a Nachahmung (imitar) e a Nachmachung (fazer igual). Diz Kant (1963, § 47, p.239):

É preciso abstrair a regra do fato, isto é, do produto, junto ao qual outros podem medir seu próprio talento, para tomá-la [a regra] como modelo, não para a Nachmachung, mas para a Nachahmung. Como isso é possível, é difícil de explicar.

A diferença é que Winckelmann não tem uma noção de gênio como Kant e dispensa ainda uma certa atenção ao produto, o que não implica que não pense numa "variação" entre o imitado e o objeto resultante da imitação. Veja-se na seqüência do comentário sobre o Laocoonte, em Reflexões, como é compreendida por ele a "produção artística" junto aos gregos: "A expressão de uma alma tão grande ultrapassa muito a representação da bela natureza: o artista devia sentir em si mesmo a força do espírito que o fazia exprimir-se através do mármore" (Winckelmann, 1975, p.53). Outro agravante para a noção de imitação é a presença da alegoria na arte e na mitologia dos gregos. ${ }^{20}$ Embora os gregos respeitem o princípio da nobre simplicidade neste terreno, não é fácil captar as significações de suas figuras alegóricas. "Não podemos negar que o significado de muitas figuras alegóricas dos antigos repousa sobre meras suposições, que por isso não podem ser empregadas universalmente por nossos artistas. ${ }^{21} \mathrm{Na}$ verdade, toda a mitologia da Antigüidade constitui para Winckelmann um tecido (Gewebe) alegórico que, antes de tudo,

20 A alegoria também deve conduzir a pintura moderna. Um mestre moderno louvado por Winckelmann é Rubens (Winckelmann, 1975, p.67). O tópico da alegoria será maciçamente criticado em Winckelmann por Goethe, Hegel, Schelling e Schopenhauer, pois o alegórico é o domínio da redução seca e árida do sensível ao conceito, enfim, ao não-artístico em sentido pleno. A contrapartida do alegórico na estética da época de Goethe é predominantemente o conceito de símbolo, que expressa mais adequadamente a união entre idéia e sensibilidade, dando espaço, por exemplo, à noção da bela individualidade. 
está marcado por um traço enigmático. "Mas toda a alegoria tem algo de enigmático [Rätselhaftes], como diz o próprio Platão acerca da arte poética, e não é feita para cada um" (Winckelmann, 1991, p.119). Logo, o conceito de imitação deve ser amplo o suficiente para dar conta desse dado enigmático da arte grega.

Entretanto, em vez de tomar esta análise de Winckelmann do Laocoonte como testemunho de sua flexibilidade, poderíamos também argumentar que ela é uma exceção, ou seja, apenas um esforço para interpretar uma escultura estranha ao seu princípio de definição da arte grega. Considerando o todo desse texto de juventude, as Reflexões..., tudo indica que tenha sido esta a intenção de Winckelmann, já que todos os seus conselhos de imitação se referem mesmo a aspectos meramente exteriores da escultura grega (belo contorno, panejamento etc.). Mas quem garante que não haja uma intenção mais profunda, até irônica, por trás desses conselhos dados aos seus contemporâneos? Seja como for, o texto das Reflexões... permite mais de uma leitura, justamente por sua articulação temática, que apresenta duas partes: uma primeira, mais geral, refere-se à necessidade de os modernos imitarem os antigos, uma vez que a arte destes é superior à daqueles; uma segunda parte é mais específica, e refere-se à particularidade e às qualidades das obras de escultura e pintura da Antigüidade e ao modo como podemos imitá-las..$^{22}$ $\mathrm{O}$ texto inicia com uma referência à questão da imitação de obras gregas, no caso específico, esculturas recolhidas em Dresden - na época uma das cidades mais florescentes da Alemanha - e que servirão de modelo para os artistas modernos. Winckelmann propõe-se a esclarecer como deve ser essa imitação. E logo de início vai afirmando a superioridade da arte dos gregos: "o único modo de nos tornarmos grandes e, se possível, inimitáveis é imitar os antigos" (Winckelmann, 1975, p.39-40). Nas dez páginas seguintes, trata de especificar, em linhas gerais, a superioridade dos gregos e a fraqueza dos modernos. Acerca disso, temos as seguintes idéias: os gregos eram livres, imitavam segundo a natureza; possuíam um espírito atlético e saudável, não corrompido como o dos modernos; buscavam uma beleza ideal a partir da natureza; não faziam mera cópia dela, mas a apreendiam como ideal. Esta beleza ideal era, junto a eles,

21 Esclarecimentos (Winckelmann, 1991, p.105). Estes esclarecimentos [Erläuterungen], com a missiva [Sendschreiben], presentes na edição alemã, foram escritos por Winckelmann em 1756 para a segunda edição da obra. A edição brasileira infelizmente não reproduz esses dois textos fundamentais.

22 Na verdade, essas duas partes não estão separadas claramente, pois já na primeira se fala das particularidades dos gregos. 
sublime. A natureza era unida, espírito e corpo em perfeita harmonia, ao contrário dos modernos, que se caracterizam pela cisão. ${ }^{23}$ Só os gregos conhecem a exatidão do contorno. A segunda parte do texto, voltada para os detalhes, refere-se quase totalmente às qualidades das esculturas e às possibilidades, para os modernos, de imitá-las. No final do texto, trata-se brevemente da pintura antiga que, conforme reconhece Winckelmann, não era tão desenvolvida quanto a moderna. Esta é superior principalmente por ter conhecido o conceito da perspectiva. Quanto à imitação em si das obras antigas, Winckelmann sugere aos seus contemporâneos vários procedimentos, técnicas materiais mesmo, para se conseguir efeito idêntico ao que os antigos conquistaram. Isso se faz necessário uma vez que os modernos não possuem mais o "dom natural” dos gregos. Eles devem procurar desenvolver métodos de reprodução de estátuas gregas, por exemplo, por meio de modelos de cera. Em síntese, Winckelmann em seu texto situa as qualidades que distinguem as obras da Antigüidade com base na abordagem de cinco tópicos: 1 . bela natureza; 2 . exatidão do contorno (só pode ser ensinada pelos gregos; mantém-se mesmo sob a vestimenta); 3. panejamento (a vestimenta era natural; tecido leve etc.); 4. caráter geral que distingue as obras gregas: "nobre simplicidade e grandeza serena" (também na literatura - e esse princípio é histórico: houve um início obscuro na arte grega, só no período clássico ela adquire a calma); 5. métodos de trabalho bastante simples, mas não menos complexos (usavam privilegiadamente modelos de cera, mas também de barro; as regras dos gregos eram mais precisas e menos equivocadas do que as dos modernos; entre estes Miguelângelo soube, por vezes, adequar-se ao gosto genuíno da Antigüidade).

Nesse modo de argumentação das Reflexões..., pode-se notar que os avanços de Winckelmann, em termos de uma nova estética, convivem intimanente com alguns aspectos problemáticos em sua teoria: em primeiro lugar, temos a valorização da Antigüidade, fato de ilimitada importância para a cultura européia. Todos, a seguir, passarão a prestar especial atenção aos antigos. Em segundo lugar, vem a importância disso

23 Nessa última distinção se anuncia o que apontávamos como a "ambígua riqueza" de Winckelmann: forçando um pouco a leitura, poderíamos dizer que sua influência sobre os contemporâneos se deu mais pelo fato de ter distinguido a natureza dos modernos do que de ter distinguido a dos antigos. Especificando os antigos, ele reafirma com mais ênfase a natureza cindida dos modernos. Essa questão é central para Kant, Schiller e F. Schlegel. Schiller até mantém essa "dialética" de Winckelmann em suas considerações históricas junto à relação dos conceitos de ingênuo e sentimental em Poesia ingênua e sentimental bem como nas idéias de "forma viva" (carta XV), "terceiro caráter" (carta III) e "impulso lúdico" (carta XIV) em Cartas sobre a educação estética da humanidade. 
para a história da arte, pois com Winckelmann introduz-se a descrição nesta disciplina, rompendo com as estéticas normativas. Winckelmann privilegia o objeto na análise. ${ }^{24}$ Em terceiro lugar, com o reconhecimento da Antigüidade, vem a confirmação da especificidade dos modernos, o fato de eles serem radicalmente distintos dos antigos. Na Alemanha, vai cessar, a partir de então, a influência irrestrita da cultura latina, tendo em vista essa tomada de consciência da diferença histórica. Com este terceiro ponto evidenciam-se os aspectos contraditórios da obra de Winckelmann, e é neles que se aloja a questão do efeito. O principal problema de suas concepções reside no conceito pouco consistente de imitação das obras antigas. ${ }^{25}$ Chama atenção o fato de que os pontos problemáticos de seu pensamento são decorrências de suas próprias teses, as quais ele não levou às últimas conseqüências. Esse ponto de vista da imitação inscreve Winckelmann nas estéticas normativas, para as quais há um modelo de arte a ser seguido. Por conseguinte, surge a questão do efeito, pois a obra de arte modelar exige um fim bem definido ao qual deve obedecer a produção da obra. Em Winckelmann, o efeito está intimamente associado à idéia da perfeição, de harmonia que deve possuir uma obra de arte: é preciso que a obra de arte seja harmoniosa para que consiga, junto aos modernos (seu público), restabelecer a união que se perdeu. Mas se os antigos são diferentes de nós, eles o são em princípio, e a imitação não vai resolver o problema da arte moderna, que é cindida, radicalmente diferente da dos gregos. Em vez de pensar no modelo, numa arte que pudesse surtir o efeito da perfeição, Winckelmann, de acordo com suas intuições radicais, poderia ter postulado uma arte própria para os modernos. Esta lacuna será percebida sempre mais claramente pelos autores posteriores da época de Goethe (F. Schlegel, Hölderlin etc.), embora seja de Winckelmann o mérito incontestável de ter lançado o problema.

\section{Lessing: teatro e estética}

24 O método descritivista de Winckelmann é criticado pelos românticos, como, por Moritz (Szondi, 1974, p.86 ss). E. Schlegel, seguindo a exigência de Herder, "de que faltaria um Winckelmann em vista dos poetas" (Sobre a recente literatura alemã, Sturm und Drang, 1949, p.250), buscará em seu estudo de juventude, intitulado Sobre o estudo da poesia grega (1795-1797), desempenhar o papel de um Winckelmann mais poético, ou seja, procurará preencher a lacuna mais ideal e espiritual nele ausente.

25 A incoerência desse preceito acentua-se mais fortemente na afirmação já referida de que os antigos são inimitáveis, mas que é preciso imitá-los (Winckelmann, 1975, p.40). 
Para Heinrich Heine, um dos maiores poetas líricos da língua alemã, a Alemanha, desde Lutero, não produziu nenhum homem maior e melhor do que Lessing. Enquanto aquele libertou a Alemanha da tradição, ressaltando a importância da palavra bíblica, este a libertou da tirania da palavra, elevando-a e emancipando-a para o espírito. Aquele fez uma reforma religiosa, este uma reforma estética (Heine, 1991, p.80). ${ }^{26}$ Gotthold Ephraim Lessing teria sido a crítica viva de sua época: um polemista e humanista. E, por causa disso, pelo seu ímpeto a favor da formação e educação do gênero humano e pela liberdade de pensamento, foi uma pessoa perseguida, sofrendo a censura do poder vigente, o poder de uma Alemanha tomada por tiranias e pelo absolutismo. Também teve problemas com a Igreja da época, por causa de suas idéias liberais. Pode-se dizer que Lessing era um verdadeiro esclarecido [Aufklärer], um defensor da livre opinião que se opunha aos exageros (por exemplo, à idéia de pátria, à de um estado militarizado como era o caso da Prússia de Frederico, o grande, logo após a guerra dos sete anos). Na vida pessoal também foi infeliz, pois sua esposa morreu logo após o parto do seu primeiro filho (Heine, 1991, p.80-5). ${ }^{27}$ De sua obra costumam-se destacar dois campos de preocupações básicas: por um lado, o teatro e, por outro, a estética em sentido mais amplo. Para Otto Mann, o teatro constitui em Lessing a poética, uma vez que esse é o centro das atenções neste âmbito (Mann, 1961, p.107). A estética, por sua vez, define-se pelas famosas considerações em torno da diferença entre a pintura e a poesia, ou melhor, entre artes figurativas e artes poéticas, presentes no ensaio sobre o Laocoonte. É nesses dois campos que também podemos visualizar a presença de uma estética do efeito em Lessing, pois dentre os três autores que se está examinando é nele que mais fortemente se acentua esta questão.

\section{A poética}

No campo das preocupações dramatúrgicas de Lessing, pode-se notar que, por um lado, ele se empenhava por um teatro livre das regras

26 Sobre Lutero, pode-se dizer que também assinalou a importância da língua alemã, tendo sido um de seus maiores divulgadores, embora não se possa considerá-lo, como alguns acreditam, o criador de sua versão moderna (Theodor, 1963, p.237-42). Quanto à relação, em Lessing, da palavra, a letra, com o espírito cf. os "Axiomata contra Goeze" (Lessing, 1965, p.53-5).

27 Para Herder, o espírito de Lessing se caracteriza por uma "argúcia em desmembrar conceitos" [Scharfsinn im Zergliedern] (Sturm und Drang, 1949, p.232). 
do classicismo francês, as quais identificava como emanando do regime absolutista e sendo justificadas por ele; por outro, lutava por um teatro nacional alemão autônomo (as duas coisas andavam juntas), que não sofresse a interferência das regras externas (dos franceses). Esse teatro alemão não era defendido em vista de um nacionalismo, pois Lessing era sobretudo um iluminista que pensava num teatro universal, embora dirigido para a classe burguesa, tendo em vista que o povo em geral não poderia mesmo ser alcançado pelo teatro. Para o povo, o gênero mais adequado seria a fábula, e Lessing chegou até mesmo a elaborar algumas fábulas e escrever artigos sobre ela. Esses dois objetivos encontram-se no texto Dramaturgia de Hamburgo, como interpreta Anatol Rosenfeld: "O fulcro e a meta da Dramaturgia de Hamburgo é a luta por um teatro nacional e um teatro burguês" (Lessing, 1991, p.16). ${ }^{28}$ Dentro desse intuito, sua dramaturgia ataca privilegiadamente dois alvos: em primeiro lugar, o classicismo francês e, em segundo, Johann Christoph Gottsched, o defensor de um teatro alemão afrancesado, autor de um Ensaio sobre uma arte poética crítica [Versuch einer critischen Dichtkunst] de 1730. Embora Gottsched estivesse certo em defender um teatro nacional, ele não o estava na medida em que suas concepções eram inadequadas, como observa Anatol Rosenfeld: "Bom senso, decoro, imitação da bela natureza, fantasia contida pela raison, verossimilhança, as três unidades dramáticas (de lugar, tempo e ação), regularidade, estrutura arquitetônica simétrica e fechada etc. eram para ele leis de validade absoluta para a tragédia" (Lessing, 1991, p.16). Gottsched, que criticava o teatro ambulante e defendia o literário, postulava um teatro que se dirigisse para um público elitizado de corte, do regime absolutista. Autores como Corneille e Racine, porém, eram inaceitáveis para Lessing, pois o destinatário deles era um mundo artificial e desumano; logo Gottsched não era de fato seu verdadeiro alvo. ${ }^{29}$

Para a estética do período de Goethe, as considerações de Lessing sobre o teatro são de vital importância, uma vez que com elas se dá um início de rompimento substancial com as estéticas normativas. Os pontos destacáveis da Dramaturgia de Hamburgo encontram-se no seguinte

28 Publicada em 1768, essa obra é o resultado da atividade de Lessing como crítico de teatro, atividade que consistia em comentar peças e apresentações que aconteciam no teatro de Hamburgo.

29 A dureza com a qual Lessing trata dele na $17^{\circ}$ carta sobre literatura, em que diz "Seria de se desejar que o senhor Gottsched nunca tivesse se envolvido com teatro", não nos deve levar à opinião contrária. E isso porque uma das características de Lessing é defender suas idéias atacando alguém (cf. essa carta em Lessing, 1962, p.41-6). 
modo de argumentar: ao opor Aristóteles aos franceses, Lessing volta-se contra as regras abstratas e rígidas e ressalta o papel da catarse.$^{30}$ Para isso, ele precisará reinterpretar Aristóteles, de modo que não coincida com o das regras; isso será feito por meio de um reexame das duas noções basilares da teoria da catarse, os termos temor e compaixão. Como se verá melhor a seguir, Lessing dirá que não se deve empregar os termos terror e compaixão para definir a catarse, e sim o par temor e compaixão, uma vez que o temor se dá entre homens que são iguais, ao passo que o terror implica a existência de príncipes e reis, remetendo ao despotismo e à tirania (Lessing, 1991, p.20). Além disso, ressaltará, tal como fará Herder, o autor de teatro enquanto gênio (Shakespeare), aquele que não se atém às regras e que fala diretamente à alma do espectador. ${ }^{31}$ Isso não significa que Lessing pense, no que toca a esse ponto, como os partidários do Tempestade e ímpeto. Ao contrário, não lhe agradava o individualismo exacerbado que esse movimento propagava; interessava-lhe muito mais o coletivo. Por isso, também mantém o teatro dentro de certos limi-

30 A relação de Lessing com Aristóteles é muito forte, de tal modo que muitas vezes buscou-se minimizar suas reflexões no campo da poética por causa da influência aristotélica. Contra isso se voltou Wilhelm Dilthey, que considerou um erro avaliar a originalidade de Lessing somente por meio do Laocoonte, sob o pretexto de que sua dramaturgia fosse mera repetição de Aristóteles, tanto que coloca a dramaturgia acima do Laocoonte. "A dramaturgia possui uma originalidade muito mais profunda do que o Laocoonte" (Dilthey, 1907, p.39). Isso não significa afirmar que não há a presença do Estagirita em suas idéias. "A poética de Aristóteles é o fundamento da estética de Lessing" (p.23). Aristóteles é insuperavelmente importante, mas não como autoridade, e sim como precursor em termos de pensamento, tanto que todos os seus passos são para Lessing corretos (Mann, 1961, p.143). É preciso, porém, segundo Lessing, continuar sua reflexão. E é neste ponto que Lessing se distingue, pela primeira vez na história, de uma estética normativa. De Aristóteles ele aceita e aprofunda a idéia da diferença entre história e poesia: a poesia deve expor o homem do modo como ele agiria (possível) segundo certas circunstâncias, e não como ele simplesmente age (real e necessário). A tragédia não deve só expor as paixões, mas as condições de um caráter trágico que as carrega, expor a gênese das paixões desse caráter. Desse modo, Lessing toca numa das verdades mais centrais que envolve filosofia, poesia e história (Dilthey, 1907, p.41). A essência da poesia seria a ação; esta, porém, deve expor uma completeza interna, que só se mostra num caráter humano e verdadeiro, no movimento livre de suas paixões (Diltheyy, 1907, p.44; sobre esse assunto cf. também as análises de Lukács, 1978, p.123-57).

31 Até 1750 a noção de gênio era entendida como mera capacidade natural ou como fogo da juventude. Foi Young quem deu a esse conceito uma nova face, em seu livro Conjecturas sobre a composição original (1759), quando o referiu à capacidade criativa imediata do poeta, contra as regras dos antigos, defendidas pelos humanistas da época (Mann, 1961, p.108). Para o desenvolvimento e nascimento da noção de gênio, contribuiu o redescobrimento, no século XVII, de Longino (Viëtor, 1952, p.238, 248 e a nota 13). Deve-se notar que em Lessing há espaço para a noção de gênio, mas menos para a de sublime; as duas noções estão desvinculadas. Isso é conseqüência de Lessing estar mais para Aristóteles do que para Longino, e é a tragédia que importa, enquanto é burguesa, sem que se permita heroísmo e elevação (Viëtor,1952, p.258) 
tes, sendo-lhe a questão dos gêneros de suma importância. Segundo sua concepção, é preciso sempre postular uma certa compreensibilidade nesse assunto e afastar os exageros, o que apenas é possível quando o teatro é fiel ao gênero dramático. Não obstante, assim Lessing também não será tão ousado quanto Herder, e nisso reside uma certa limitação em termos de um afastamento definitivo das poéticas normativas.

Vejamos mais de perto esses pontos destacáveis em Lessing, selecionando dois movimentos de reflexão: primeiramente, a crítica a Voltaire e o elogio a Shakespeare; a seguir, a questão da catarse, o ponto alto da Dramaturgia de Hamburgo. Quem regula a crítica a Voltaire e a valorização de Shakespeare é Aristóteles e o ensejo é dado pela questão do possível papel reservado a um fantasma no teatro. Lessing refere-se ao desagrado de Voltaire quanto ao modo de aparecimento do fantasma (espectro) no Hamlet; este seria para Voltaire de mau gosto numa tragédia e isso porque ninguém mais, nos tempos iluministas, acreditaria em fantasmas. A resposta de Lessing a esta posição de Voltaire se orienta no sentido da função estrutural que pode e deve ter tal fenômeno numa tragédia. Nesse sentido, Voltaire não teria compreendido bem a questão, tanto que numa de suas peças um espectro aparece em plena luz do dia, numa assembléia, sendo visto por todos. Esse espectro seria totalmente inadequado, pois seria frio, bem "refinado", como convém a Voltaire. Já no Hamlet, o espectro surge sozinho, e cumpre totalmente as exigências da verossimilhança: o espectador pode acreditar nele (Lessing, 1991, p.39-41). ${ }^{32}$ Segundo Lessing, o fantasma de Voltaire pode até ser mais filosófico, mas o de Shakespeare é bem mais poético. Continuando a crítica a Voltaire, Lessing destaca a autonomia que qualquer obra poética sempre deve possuir, independente de seu autor. Voltaire estaria sobreposto à obra, sendo aplaudido após o espetáculo de seus dramas. Que contraste não haveria entre ele e Homero, cuja obra teria sobrevi-

32 No que toca à peça Hamlet, o espectro aparece em mais de uma cena. Lessing está se referindo à quarta cena do terceiro episódio, logo após Hamlet ter assassinado Polônio, que estava escondido atrás da cortina. Como se sabe, o espectro é o rei morto, pai de Hamlet, que abre a peça, surgindo para os guardas, à noite. Sobre o sentido dele, não há uma única versão: pode ser interpretado como tendo apenas uma função estrutural, a de fazer saber a Hamlet a realidade dos fatos; no entanto, é possível também uma leitura psicológica, que busca situá-lo como algo da mente problemática de Hamlet (nesta direção vai Frye, 1992). Hamlet também será importante junto a F. Schlegel, em seu texto de juventude. Tomado pelo "império do entendimento", ele marcaria o traço característico da poesia moderna; sua alma seria dilacerada, marcada por um completo conflito entre a força de pensamento e a força ativa, de ação (Schlegel, 1956, p.136-8). Ainda sobre Shakespeare no romantismo alemão, é dessa época que data uma das melhores traduções dele para a língua alemã, que é precisamente a que foi empreendida por August Schlegel (cf. Shakespeare, 1921). 
vido para a posteridade sem nem se saber bem quem foi Homero! Para Lessing, a autêntica obra deve estar acima do autor, deve ser algo objetivo em si. Sobre as regras dramáticas de Aristóteles, nota que os antigos as observavam, mas os franceses nelas se acomodam. Por regras entenda-se as que se referem à unidade de ação, de tempo e de lugar, as quais, na verdade, não estão assim tão claramente estabelecidas no texto da Poética do Estagirita. Para Lessing (1991, p.42-6), porém, só a unidade de ação é que seria primordial aos antigos.

O ponto alto de todo o texto surge, no entanto, com as reflexões de Lessing sobre a catarse. ${ }^{33} \mathrm{~A}$ matéria inicial para tanto é fornecida pela peça do dramaturgo Weisse, um contemporâneo, intitulada Ricardo II. Para Lessing, o senhor Weisse de início já cometeu um erro, que é o de tentar imitar uma peça de um outro autor, e ainda mais quando este é Shakespeare. Antecipando a idéia de crítica de arte e se opondo às poéticas normativas, Lessing ressalta que o bardo necessita não ser imitado, mas ser compreendido. Além disso, segundo a teoria de Aristóteles, a peça de Weisse seria inteiramente desaprovada, pois excede no terror provocado. É nesse momento que entra em cena a especificação do conceito de catarse. Na verdade, o conceito grego de Aristóteles não deveria nunca ser traduzido na Poética por terror e sim por temor, pois é o temor que se dá entre semelhantes e a tragédia exatamente expõe o infortúnio de alguém semelhante a nós (Ibidem, p.52-3). Ou seja, a expressão temor cumpriria muito mais as exigências dramáticas ligadas ao convencimento e não a uma mera submissão a um poder instituído. E o termo temor deveria ser pensado segundo toda a obra filosófica do Estagirita, especialmente segundo a Retórica, bem como deve vir acompanhado pela compaixão, pois ambos se complementam. E justamente quanto a isso é preciso ajustar as contas com um outro oponente de Lessing, que é Corneille. No confronto entre ambos, torna-se visível a presença de uma estética do efeito em Lessing. A crítica do alemão ao francês se dá pelo fato de este ter dispensado o medo do âmbito da tragédia e de só ter considerado necessário que a tragédia suscite a compaixão (Ibidem, p.57). ${ }^{34} \mathrm{O}$

33 Sobre esse tópico em Lessing e sua relação com Aristóteles, há um excelente estudo, presença obrigatória nas bibliografias sobre Lessing, que é o de Kommerell, 1970, ao qual remetemos o leitor (há uma tradução para o espanhol). Trata-se de um amplo estudo focalizando muitos aspectos lingüísticos e de uso das fontes gregas da época.

34 Cf. Corneille, 1963, p.75-87. Para Kommerell, tanto em Lessing quanto em Corneille os efeitos que incidem sobre o espectador não são exteriores à obra e sim integrantes dela, complementando-a. Ambos concordariam quanto à questão de o efeito se relacionar à forma da tragédia; porém, consideravam os conceitos de "medo e compaixão" como dados e não teriam 
problema está exatamente no pressuposto de que a tragédia tem seu sentido de existência enquanto uma espécie de entretenimento com a desgraça alheia, de que isso é capaz de purificar nossa alma. O que incomoda Lessing é essa afirmação de narcisismo (da classe dominante) expressa nas idéias de Corneille e a subseqüente perda do efeito vivo e transformador da tragédia que elas acarretam. ${ }^{35}$ Para contestá-lo, Lessing mobiliza as idéias de Moses Mendelssohn, à época seu amigo e postulador de uma teoria das paixões segundo o empirismo dos ingleses. Neste caso, conclui que a noção de compaixão em Aristóteles seria compreendida como afeto. Um tipo de compaixão seria a filantropia, mas esta não seria a mais adequada a ser suscitada pela arte dramática. $\mathrm{Na}$ verdade, os conceitos de temor e compaixão deveriam andar juntos, embora um contenha implicitamente o outro. O temor é necessário porque nos atinge primeiramente, nos faz não só sentir compaixão de quem sofre, o necessário distanciamento, mas constantemente nos lembra de nossa condição humana. As duas paixões estariam assim em perfeito equilíbrio (Ibidem, p.65), tanto que Aristóteles teria escolhido justamente estas porque seriam suficientes para explicar todas as outras paixões e todas as regras das quais trata. O fim moral também estaria essencialmente relacionado a estas paixões somente e a nenhuma outra; a purificação não se refere a todas as paixões, como pensaria Corneille. E assim, seriam respeitados os limites do gênero trágico, e não se buscaria amainar o seu efeito por meio de uma suposta moderação, de um suposto meio termo nas regras aristotélicas (p.71-80). ${ }^{36}$

percebido como forma e efeito trágicos nestes dois conceitos são uma coisa só. Em Aristóteles importaria muito, neste caso, a idéia de organismo vivo (o que encontraríamos também em Schiller: estado estético, e em Nietzsche: estado dionisíaco) (Kommerell, 1970, p.63-4 e p.63-107). No caso dessas duas últimas referências, indicadas por Kommerell, poderíamos perguntar até que ponto não seria o caso de substituir a noção de catarse pela idéia de prazer estético, um prazer que é interno, inerente e imanente e dispensa a idéia de público. Goethe (1962, p.172) expressou essa exigência ao dizer: "Aristóteles compreende a catarse como acabamento reconciliador".

35 Sobre a posição de Corneille em relação ao teatro, Viëtor afirma que nele o sentido da catarse seria o de suscitar a admiração por heróis da vontade que surgem em cena. $\mathrm{O}$ temor ou medo não cabe no âmbito da catarse porque se opõe a essa admiração. A ênfase na noção de vontade teria sido muito comum na França da época de Luís XIV, e isso porque a França se sentia a herdeira viva do império romano. Os alemães poderão ir contra este classicismo justamente porque redescobrem a Antigüidade (Winckelmann). Como já foi visto, essa Antigüidade não é a da renascença e do classicismo do século XVII (que se refere à Arcádia, cf. Poussin), mas a própria Grécia; já os franceses agarram-se ao estoicismo romano: o que vale nos povos românicos do século XVII é o patético, segundo J. Burckhardt; o mundo da corte seria visto como sublime (Viëtor, 1952, p.235-6). 


\section{A estética}

Atentemos agora para um outro aspecto da obra de Lessing, de certo modo bastante conhecido na história ocidental da reflexão sobre arte, que é sua refutação da idéia de Horácio do ut pictura poiesis ("pintura igual a poesia" da "Epistola ad Pisones", A poética clássica, 1992, p.65). Esse tópico de sua obra marcou sobremaneira a geração seguinte da estética da época de Goethe e, em certa medida, de modo negativo, pois quase todos, à exceção de Goethe, buscarão afirmar a superioridade da poesia sobre as artes figurativas. No entanto, o que mais vale nessas observações de Lessing, segundo Rosenfeld, não é tanto sua crítica à poesia pintura, e sim o reconhecimento do domínio específico das duas artes (Lessing, 1991, p.12-3). Essas reflexões encontram-se no ensaio Laocoonte ou sobre os limites da pintura e da poesia [Laokoon oder Über die Grenzen der Malerei und Poesie], surgido em 1766. Lessing toma a escultura do Laocoonte para fazer suas reflexões sobre a poesia e a pintura, distinguindo ambas a partir de seus modos de expressão: a pintura, representando as artes figurativas, não seria igual à poesia, pois afirma-se no espaço, e não admite os exageros, manifestações de exaltada alegria e sofrimento e isso simplesmente porque não dispõe dos meios (exclusivos da poesia) para tanto. Só a poesia, dando-se na ordem temporal, pode expressar estes sentimentos. Por essa distinção,

36 Quanto à adaptação das regras aristotélicas por parte de Corneille, Lessing se dá ao trabalho de selecionar seis "erros" de leitura, em que exatamente sempre ressalta essa questão fatal em Corneille do "meio termo" (Lessing, 1991, p.91-9). Em relação aos limites e objetivos em geral do gênero dramático em Lessing, ressalte-se que este não foi só crítico, mas também poeta, embora não se considere um, como afirma no fim da Dramaturgia de Hamburgo: "Não sou ator nem poeta" (p.9). Como escritor de teatro, sua preocupação era manter o gênero em seus limites; ele é considerado o fundador do drama burguês. Dentre sua obra está uma comédia, considerada por W. Dilthey uma das mais belas da língua alemã, que é Minna von Barnhelm (comentada em Dilthey, 1907, p.53-9). O que a caracteriza é a economia poética; tudo se passa numa taverna no espaço de um dia. O conflito é bem determinado: ele se dá entre a militarização do recém-criado Estado da Prússia e o princípio do humanismo, entre Telheim e Minna von Barnhelm. Quem acaba vencendo é o humanismo de Minna, mas porque esse princípio já residia em Telheim, que apenas fora dominado momentaneamente pelas circunstâncias e a ideologia de sua época. Para Dilthey, o que acabou vencendo foi o amor e o humanismo em Telheim, "a mais bela figura de caráter da literatura alemã" (Dilthey, 1907, p.53). Aliás, toda a peça é plena de riquezas, em termos das personagens secundárias. O humanismo, aliado à valorização da família, é também tema de duas outras peças de Lessing, muito parecidas entre si: Emília Galotti (1772) e Miss Sara Sampson (1755). Na primeira peça, a personagem Sara Sampson mostra no diálogo com Marwood ( $4^{\circ}$ ato) que, acima de tudo, existe a confiança no amor e na sinceridade humana; do mesmo modo, Emília e seu pai, na segunda peça, são o exemplo da união humana e familiar contra a tirania e o poder. 
Lessing desejava, como já foi mencionado, combater a literatura idílica, que somente descreve as coisas, e mostrar que a literatura, a poesia, tem um domínio próprio que é o da ação, segundo o princípio do tempo. A poesia progride no tempo, enquanto a pintura expõe simultaneamente os objetos no espaço. ${ }^{37}$ Em outras palavras, o que aqui está sendo distinguido é a prosa da poesia. Em termos sucintos, a Parte XVI do texto patenteia o seguinte: a poesia recorre aos sons articulados no tempo e a pintura às figuras e cores no espaço. Os corpos são objetos da pintura, as ações o são da poesia; a pintura pode imitar ações, porém, só de maneira alusiva, assim como a poesia só deve descrever corpos a partir do ritmo da ação. Para esclarecer essa diferenciação, Lessing (1949, p.77-85) examina o exemplo de Homero: sua obra operaria essencialmente segundo a especificidade da poesia; o poeta não descreve os objetos, mas conta-nos a história deles. E quando pinta, continua Lessing na Parte XVII, é para "tornar as idéias, que em nós suscita, mais vivas". Nesse caso, percebe-se que o problema da poesia descritiva reside no fato de se deter nas partes e esquecer o todo, o que acarreta a perda da ilusão, algo indispensável à poesia. Em suma, pode-se dizer que o Laocoonte permite esclarecer duas coisas: 1. a arte deve possuir limites e fundamentos; deve-se marcar o que nela importa e o que lhe é intrínseco, no que toca ao seu procedimento conveniente; 2 . é preciso especificar o que é particular, característico às diferentes artes. O ponto 1 é mais ontológico e necessita da comparação das duas artes, enquanto o 2 é mais específico, mas ambos se unem pelo fator imaginação, mesmo que uma arte se refira ao olho e outra ao ouvido, pois é à imaginação que realmente se dirigem. Segundo Otto Mann, é o fim estético que determina as regras de cada arte e Lessing afirmaria o completo caráter de idealidade intrínseca a cada arte; a realidade não serviria como critério de distinção de uma obra de arte. Em outras palavras, o que importaria não seria o objeto em si, mas o que é imaginado, exposto (e não afirmado), tal como já teria dito Aristóteles: o campo da arte não é o real, mas o possível (Mann, 1961, p.103-6).

Quando se trata do Laocoonte, a comparação entre Lessing e Winckelmann é inevitável, e isso ainda mais porque o diálogo entre ambos está no próprio texto de Lessing. Winckelmann considera os excessos de dor manifestados por Laocoonte na obra de Virgílio (Eneida, II, 222-4)

37 A idéia de progressão em poesia será retomada no pensamento estético de Friedrich Schlegel. Confira-se o fragmento 116 do Ateneu: "A poesia romântica é uma poesia universal progressiva..." (Schlegel, 1994, p.99). 
como um sinal de decadência da arte antiga que, na sua fase clássica, não admitia gritos e choros. Lessing o contradiz, afirmando que os antigos consentem a livre manifestação da dor na literatura e no teatro, mas não nas artes plásticas. A razão disso residiria na diferença das artes e não no declínio da arte clássica (Lessing, 1991, p.11). Em outras palavras, para Lessing, a figura de Laocoonte interessa para distinguir o princípio da escultura e da poesia, ao passo que Winckelmann busca nesta obra somente explicitar o ideal grego. Independentemente da posição particular de Lessing em relação a Winckelmann, porém, é possível estabelecer os seguintes pontos de concordância e divergência entre ambos (Mann, 1961, p.89-162): de modo geral, o que percebemos em Winckelmann é o domínio do objeto, a obra de arte em sua realidade, ao passo que em Lessing entramos no reino do subjetivo e da imaginação, do mundo supra-sensível. Naquele a obra de arte por excelência é a escultura, neste é a tragédia, o drama. Assim como para o primeiro só há uma beleza, que mais puramente se desenvolveu na Grécia, para o segundo só há uma tragédia perfeita: a grega. Winckelmann era o grande conhecedor culto da arte; sabia captar as impressões nesse domínio, tomar as obras de arte como figuras e efeito presentes; esse era o seu talento, que se aproximava do teórico cientista e do filósofo historiador. Lessing já é mais um julgador de arte e, assim, um ontólogo; ele se mostra um juiz que continua o debate, em relação ao Laocoonte, em que a adoração winckelmanniana pela obra apenas se detém. Ele aceita a metáfora do mar e continua a questão, perguntando se há mesmo essa liberdade do escultor para plasmar assim um conteúdo poético ou se ele teve de ficar confinado a um único instante, que é mais oportuno e adequado para a sua arte. Winckelmann imputa à arte uma instância objetiva: ela media um ideal de vida. Lessing somente atribui a ela um efeito subjetivo - como se vê, ambos consideram o efeito como algo essencial a uma obra -, demonstra interesse pela experiência estética enquanto um todo (há neste ponto mais parentesco entre Lessing e Kant do que entre Winckelmann e Kant, em razão do espírito crítico do primeiro). Assim, é mais precursor de Kant e Schiller, uma vez que não fica preso ao objeto em si, mas ao efeito dele sobre o sujeito, no fato do sentimento estético, que é sempre referido à arte e não ao objeto só porque é belo. ${ }^{38}$ Para Lessing, nunca estamos somente referidos à natureza. No caso do Laocoonte, essa diferença fica bem clara: Winckelmann compreende a arte relacionada diretamente ao objeto, uma arte real. Lessing, pelo contrário, questiona essa obra pelo modo como consente o livre jogo da imaginação. 


\section{Herder: a valorização da história}

Depois de passarmos por Lessing e Winckelmann, chegou a vez de Johann Gottfried Herder. Dentre seus interesses destaque-se sua inclinação por pesquisas relativas às canções populares [Volkslieder] e pela valorização do papel da língua materna para a cultura de um povo. Dos autores que estão sendo aqui examinados, ele foi o único que participou ativamente do movimento Tempestade e ímpeto, no qual sofreu grande influência de Hamann, o mago do norte, autor de escritos de cunho fragmentário e aforístico, geralmente um tanto oraculares. Todas as obras de Hamann constituem-se como uma crítica ao racionalismo das luzes e um enaltecimento do aspecto das paixões humanas. É dele que Herder adquiriu o gosto pelo estudo das línguas maternas dos povos. ${ }^{39}$ Para o que aqui interessa, convém verificar as reflexões de Herder sobre o tema da história, na medida em que essas reflexões se encontram referidas às obras de arte. É por meio da necessidade de relacionar sempre cada obra de arte à sua origem histórica que Herder se inscreve de modo decisivo na estética da época de Goethe. Em relação a isso, vemos nele uma certa convergência com as idéias de Winckelmann, no que toca ao discernimento das diferenças históricas entre os gregos e os modernos. De Winckelmann Herder adotará o parti pris de sempre analisar a obra de arte individual e de não se basear em noções e regras abstratas.

Para que se possa avaliar essa contribuição de Herder às questões estéticas, ele que não era alguém que se dedicou exclusivamente à análise de obras de arte, uma vez que os interesses da disciplina da história o absorviam mais, examinemos seu ensaio intitulado Shakespeare (1773). Já foi observado que Shakespeare era na época usado pelos integrantes do movimento Tempestade e ímpeto para ser oposto ao artificialismo dos franceses. Shakespeare é o criador de personagens cujos caracteres são fortes, guiados pelas paixões e sentimentos: nada de artificialismo e regras. O texto de Herder se constrói nessa perspectiva. Em termos estruturais, pode-se dividi-lo

38 Conferir Schiller, carta XXVI de Cartas sobre a educação estética da humanidade: uma mulher real pode ser mais bela, mas a mulher pintada agrada mais ao juízo estético apurado (questão da aparência estética - Schiller, 1991, p.139: a mulher real pode agradar, mas somente enquanto aparência). Deve-se notar nesse contexto que isso não significa que em Kant e Schiller haja em grau maior a presença de uma estética do efeito do que em Lessing. Pelo contrário, nestes a estética do efeito encontra-se absorvida, no sentido de que está inserida no contexto do domínio específico da arte. O critério do efeito é inerente, ao passo que em Lessing nem tanto.

39 Acerca de Hamann, diz Herder: "Quem não quiser encará-lo como o cérebro de nossa literatura, encare-o como um meteoro" (Sturm und Drang, 1949, p.232). 
em quatro momentos. Três são as referências básicas: o teatro francês, Shakespeare e o teatro grego. Desse modo, temos a seguinte ordem argumentativa, que a seguir será analisada: a) o teatro grego visto a partir de seu nascimento; sua diferença em relação ao teatro francês; b) o teatro de Shakespeare - que se liga ao seu povo; sua natureza específica; c) este teatro está de acordo com o teatro antigo e Aristóteles; d) Shakespeare é referido ao pressuposto geral de Herder - a história.

Logo no início do texto, após exaltar Shakespeare e exigir que ele seja compreendido adequadamente, Herder se refere ao nascimento e à constituição do teatro grego. ${ }^{40}$ É preciso indagar por suas origens, ainda mais porque o teatro grego marca a própria invenção do gênero. O que se ressalta nos gregos é a naturalidade com que abordavam o teatro, de modo algum dirigido por regras abstratas e artificiais. Neles valia a máxima de "jamais fazer do múltiplo o simples, mas transformar o simples em múltiplo, um belo labirinto de cenas...".41 A natureza foi quem criou seu teatro e não as regras de Aristóteles, que vieram depois. Elas surgiram à medida que se desenvolvia seu objeto e não o contrário. Com isso, Herder pretende mostrar que, do ponto de vista da gênese, único pressuposto autêntico, Shakespeare está à altura dos franceses ou até lhes é superior, pois estes de modo algum se aproximaram dos gregos, embora, quando se atêm apenas às regras deles, mas não ao espírito, sustentem exatamente o contrário. O que faltaria ao teatro francês seria vida, natureza e verdade. Tendo estabelecido a relação de Shakespeare com o teatro grego, Herder chega então ao seu pressuposto de avaliação da obra do primeiro: cada povo deve encontrar o seu próprio drama. "Vamos pois imaginar um povo que, por razões que não queremos imaginar, tivesse vontade de inventar para si mesmo o seu drama, ao invés de macaquear e ficar satisfeito com a casca da noz" (Autores pré-românticos alemães, 1991, p.47). Nesse sentido, é preciso concordar que Shakespeare tem algo em comum com os gregos, embora seja diferente. Devemos considerar seu teatro como algo individual, específico, mas nem por isso infe-

40 Nessa perspectiva, já se vê uma clara diferença em relação a Lessing, pois trata-se de ver o teatro grego a partir de seu nascimento e não com base na Poética de Aristóteles. A título de comparação, é interessante notar como nos nossos três autores há uma experiência da Antigüidade sempre distinta: em Winckelmann prevalece a escultura, o plástico; em Lessing, o campo poético; ao passo que em Herder temos o histórico, no sentido da concretude de um povo. Com base nisso, pode-se perguntar: como essas três vertentes desembocaram no classicismo que marca a tradição estética da época de Goethe, o chamado classicismo de Weimar?

41 Autores pré-românticos alemães, 1991, p.42. Acerca dessa coletânea de textos traduzida para o português, é preciso que se diga que ela apresenta algumas falhas. Tanto no texto de Lenz quanto neste de Herder foram inexplicavelmente excluídos alguns trechos dos originais. 
rior ao teatro grego. Por mais distante que esteja de Sófocles, compartilha algo com ele. "E ao mesmo tempo que aquele representa, ensina, comove e forma gregos, da mesma maneira Shakespeare ensina, comove e forma homens nórdicos" (Ibidem, p.51). Sua produção caracteriza-se por ser genial, isto é, como os gregos buscou algo de próprio, mas isto a partir da história e do mundo (outro país, numa outra época) que se lhe impunha. Neste ponto, é claro, Shakespeare se diferencia dos gregos; ele não podia criar a não ser pelas condições de sua pátria. ${ }^{42} \mathrm{Em}$ vista dos modernos, deve-se mesmo considerá-lo superior aos gregos, pois ele tem muito mais a dizer aos alemães do que aqueles. ${ }^{43}$ Shakespeare seria o maior poeta nórdico. Sua obra é como uma planta, que tem seu próprio ambiente. "Tira a essa planta o seu solo, seiva e força, plantando-a no ar: tira a esse homem lugar, tempo e qualidade individual - e lhe estarás tirando alento e alma, e será apenas uma imagem da criatura." (p.57). Espaço e tempo (regras de Aristóteles) são relativos, imaginários, uma vez que o poeta cria o seu mundo de ilusão e sonhos, e esse mundo sempre possui o seu tempo e seu lugar. Para o gênio não há a realidade das regras, há a idealização delas; o poeta não se limita, expande-se (idéia de organismo que se expande). ${ }^{44}$ Isso significa que a base última do teatro e de toda poesia e arte é a história. "Toda peça, no mais amplo sentido, é History, que, é verdade, ganha mais ou menos nuanças de tragedy, comedy ... cada peça tem de permanecer ... o que é: história, ação de heróis e reis, criando a ilusão dos tempos médios" (p.62).

42 O que se pode questionar em Herder, de um ponto de vista tardio, hölderliniano, é esse pressuposto de que o artista necessita criar com base em uma espécie de natureza. "Nisso Shakespeare é o grande mestre, justamente por ser sempre e unicamente servo da natureza", diz Herder (Autores pré-românticos alemães, 1991, p.54). Pois, não poderia haver diferença na destinação poética de antigos e modernos, no sentido de a própria idéia de estar referido à natureza não ser algo comum às duas épocas? Ou seja, a perspectiva da história anula ela mesma a perspectiva da referência à natureza.

43 Isso não significa que não se deva atentar para os gregos. No texto Sobre a recente literatura alemã, lemos em relação aos gregos: "eles valem a pena ser imitados" (Sturm und Drang, 1949, p.247). Homero deve ser traduzido para o alemão, mas que se atente sempre para a posição da poesia e da linguagem próprias aos alemães. O que faltaria para estes seria, porém, um Winckelmann para a poesia: "Um Winckelmann segundo a arte somente pôde florescer em Roma [referência à vida dele, passada em grande parte na Itália]; mas um Winckelmann segundo a poesia pode também surgir na Alemanha, e abrir um grande caminho junto com seus antepassados romanos" (Sturm und Drang, 1949, p.250). Essa imitação, segundo Herder, deve estar voltada para a época moderna; aprender com os gregos, como os romanos aprenderam deles. Herder prevê em Klopstock o imitador alemão de Homero.

44 Note-se que Herder já não considera mais a poética de Aristóteles como Lessing, no sentido de que ela possa ser empregada para avaliar ou julgar uma obra de arte moderna. Herder quase que rompe com algumas noções de Aristóteles. 
O que se pode concluir dessas reflexões de Herder? Seus avanços para o pensamento estético de então localizam-se, sem dúvida, no reconhecimento do artista enquanto gênio e na relativização radical das "regras" de produção artística decorrentes dessa valorização. Ambos os aspectos emanam de uma concepção peculiar da história como um "organismo". Num sentido mais amplo, Herder já está muito próximo do núcleo da estética da época de Goethe, o que se torna transparente quando da relativização de Aristóteles; estamos aqui a um passo do início da consolidação de uma filosofia da arte de feitio idealista. Mas, apesar dos avanços, subsistem alguns pontos problemáticos, por exemplo, a dependência de uma estética do efeito, o tópico de análise proposto neste artigo. Essa subordinação se anuncia por ocasião de sua crítica aos franceses e exaltação de Shakespeare: o drama deve nos comover, nos tocar na alma. Ora, o tópico da comoção [Rührung, o comovere] é um critério típico de uma estética do efeito que não se adapta de modo algum à noção original de história em Herder. ${ }^{45}$ Veja-se a seguinte passagem em que Herder confunde as duas coisas: a historicidade (que é sempre distinta e variada) de uma obra de arte e o efeito (homogêneo e universal), em que se requer que de uma matéria contrária seja provocado o mesmo efeito. "Dado que, como se sabe, gênio é mais que filosofia, e criador algo diverso de analista, um ser mortal [Shakespeare] foi dotado de força divina para justamente de matéria contrária e através de uma elaboração totalmente diversa, produzir o mesmo efeito, terror e compaixão!" (p.49). Contra Herder, pode-se questionar: Mas será que pelo fato de haver uma matéria contrária não teremos também um efeito contrário, ou mesmo a supressão e relativização da idéia de efeito, uma vez que neste caso nem se trata mais de perguntar e insistir na idéia do efeito? Essa ambigüidade em Herder compromete seu ponto de vista histórico, embora tenha sido contraditoriamente este seu grande avanço no que concerne à abordagem de uma obra de arte. Pois desse modo, Herder ora estima, ora desconsidera o aspecto genético (proveniente de Winckelmann): se vale o ponto de vista histórico mesmo, não se podem mais analisar as obras de arte nos termos comparativos e críticos intemporais empregados ainda por Herder. Igualmente seria preciso abandonar radicalmente princípios supra-históricos absolutos (as regras de Aristóteles) e procurar ver de modo radical a obra de arte, por exemplo, a partir da idéia de organismo mesmo, tão ressaltada por Herder.

45 Esse aspecto desaparece totalmente em Kant. Cf. o $\$ 13$ da Crítica do juízo: "O puro juízo de gosto é independente do estímulo e da comoção". 


\section{Considerações finais}

Como se coloca, enfim, a questão concernente à presença de uma estética do efeito nos três autores examinados, uma vez que em todos eles ela se situa enquanto uma espécie de divisor de águas? Em Winckelmann, encontramos o autor em que ela menos aparece. A rigor, nele impera muito mais uma perseverança junto ao objeto da arte do que uma ênfase no receptor ou espectador. Alie-se a isso um forte senso histórico, a capacidade de determinar o sentido de uma obra de arte de uma outra época. No entanto, assim encontramo-nos apenas junto a um lado de seu pensamento, sem dúvida o que estava mais presente para ele. Esse lado diz respeito à sua visão dos antigos; é, portanto, retrospectivo. Mas há o outro lado, menos aparente, relacionado à nova visão do mundo moderno implicada pelo contraste com a Antigüidade, e nesse campo entra em cena a questão do efeito. É claro que aqui novamente encontramos um grande mérito de Winckelmann, que é o de conseguir, de modo indireto, desvendar claramente o que outros não conseguiram perceber à primeira vista, ou seja, a natureza cindida dos modernos. Mas como os modernos não lhe chamavam tanta atenção, Winckelmann incorreu no erro de achar que essa natureza era algo somente circunstancial, era algo que não tivesse raízes tão profundas como na realidade tinha. Desse modo, instalou-se nele a questão do efeito: em sua proposta de curar a doença moderna, em vez de tratá-la antes. Em Lessing, ao contrário, a estética do efeito já é claramente defendida. Paradoxalmente, porém, ela coexiste com uma forte defesa da autonomia do objeto estético, não enquanto realidade, mas enquanto idealidade. Isso fica mais claro no Laocoonte, em que Lessing marca bem esse ponto, embora para tanto faça uso, em sua abordagem, de elementos de uma estética do efeito. A questão do som da poesia, que se dirige ao ouvido, e a questão da imagem na pintura, que se dirige ao olhar, dão um exemplo de como suas análises operam com o efeito. Acrescente-se a isso a preocupação de ordem social presente em Lessing, que se manifesta em sua leitura da catarse. Podemos, em parte, explicar esses dois aspectos em Lessing por meio de sua relação com Aristóteles. Pois na Poética do Estagirita, que ainda não é totalmente uma estética normativa, eles se encontram também entrelaçados. A diferença é que Lessing é moderno, e o que acaba pesando é o aspecto do supra-sensível e, nesse sentido, estamos com ele a um passo da idéia romântica da poesia progressiva ao infinito. Disso decorre que as categorias aristotélicas se impõem em Lessing para alargar o domínio poético segundo as exigências modernas idealistas de mundo. Logo, se olharmos 
sua obra por esse ângulo, veremos que a idéia realista do efeito tenderá a se esvair, a ser mais um ponto de vista dentre outros, a serem determinados, depois de Lessing, por uma instância especulativa (crítica, absoluta, racional etc.). Já em Herder parece que a estética do efeito simplesmente foi uma decorrência do modo como afirmou o princípio histórico para a avaliação de obras de arte. E isso porque esse princípio foi esboçado em contraposição às poéticas normativas. Nesse sentido, a perspectiva histórica não podia ainda surgir em sua pureza. Era preciso, para desmantelar um modelo, em primeiro lugar eleger outro ou a possibilidade de existência de outros modelos. Só num terceiro momento poderá aparecer a perspectiva histórica mesma por trás desses movimentos e tornar possível a eliminação da idéia de modelo. Mas Herder não chegou a isso. Nesse sentido, sua estética do efeito significa justamente uma incorporação inconsciente de um elemento estranho: a dependência a um determinado terreno de discussão, o século XVIII.

WERLE, M. A. Winckelmann, Lessing and Herder: aesthetics of the effect? Trans/Form/Ação (São Paulo), v.23, p.19-50, 2000.

- ABSTRACT: We analyse in this article, from the point of view of an aesthetics of the effect, the sources of the so called "aesthetics of Goethe's time", according to the works of Lessing, Winckelmann and Herder. Our aim is to show that there are in those authors both an influence of the parameter of the effect, elicited by the work of art on the spectactor, and the pointing to a dimension, so to speak critical, idealistic and speculative of appreciation of the artistic phenomenon.

- KEYWORDS: Winckelmann; Lessing; Herder; aesthetics.

\section{Referências bibliográficas}

A POÉTICA clássica: Aristóteles, Horácio, Longino. Trad. direta do grego e do latim de J. Bruna. 5.ed. São Paulo: Cultrix, 1992.

AUTORES pré-românticos alemães. Intr. e notas de Anatol Rosenfeld. São Paulo: EPU, 1991.

CORNEILLE, P. Trois discours sur le poème dramatique (Texte de 1660). Intr. e notas de L. Forestier. Paris: Société D’Édition D’Enseignement Supérieur, 1963. 
DIECKMANN, H. Die Wandlung des Nachahmungsbegriffes in der französischen Ästhetik des 18. jahrhunderts. In: JAUSS, Von H. R. (Org.) Nachahmung und Ilusion. 2.ed. München: Fink, 1969. (Poetik und Hermeneutik 1.)

DILTHEY, W. Das Erlebnis und die Dichtung. 2.ed. Leipzig: Teubner, 1907.

FICHTE, J. G., SCHELling, F. Escritos filosóficos. Trad. R. R. Torres Filho. São Paulo: Abril Cultural, 1973. (Os Pensadores).

FRYE, N. Sobre Shakespeare. Trad. de S. L. de Melo. São Paulo: Edusp, 1992. (Criação \& Crítica).

GOETHE, J. W. von. Götz von Berlichingen mit der eisernen Hand: ein Schauspiel. Basel: Amerbach, 1947.

. Nachlese zu Aristoteles Poetik. In: Schriften zur Literatur, zweiter Teil. München: Deutscher Taschenbuch Verlag, 1962.

GOETZ, W. Goethe. Sein Leben in Selbstzeugnissen, Briefen und Berichten. Berlin: Tempelhof, 1947.

HEGEL, G. W. F. Werke. Frankfurt am Main: Suhrkamp, 1986. 20v. . Cursos de estética I. Trad. M. A. Werle. São Paulo: Edusp, 1999.

HEINE, H. Contribuição à história da religião e filosofia na Alemanha. Trad. M. Suzuki. São Paulo: Iluminuras, 1991.

KANT, I. Kritik der Urteilskraft, (hrsg.) Stuttgart: Reclam, 1963.

KLINGER, F. M. Tempestade e ímpeto. Tradução e notas A. Krug. São Paulo: Cone Sul, 1997.

KOMMERELL, M. Lessing und Aristoteles: Untersuchung über die Theorie der Tragödie. 4 Aufl. Frankfurt am Main: V. Klostermann, 1970.

LESSING, G. E. Ausgewählte Werke: ausgewählt und mit einem Nachwort versehen von Wolfgang Stammler, Dritter Band. München: Hanser, 1949.

. Kritik und dramaturgie. Ausgewählte Prosa, Auswahl und Einleitung von Karl Hans Bühner. Stuttgart: Reclam, 1962.

. Die Erziehung des Menschengeschlechts und andere Schriften. Stuttgart: Reclam, 1965.

. De teatro e literatura. Intr. e notas A. Rosenfeld. São Paulo: EPU, 1991.

LUKÁCS, G. Introdução a uma estética marxista. Trad. C. N. Coutinho e L. Konder. Rio de Janeiro: Civilização Brasileira, 1978.

MANN, O. Lessing: Sein und Leistung. 2.ed. Hamburg: Marion von Schröder, 1961.

PANOFSKY, E. Significado nas artes visuais. Trad. M. C. Kneese e J. Guinsburg. 2.ed. São Paulo: Perspectiva, 1979. (Debates).

SCHELLING, F. von. Cartas filosóficas sobre o dogmatismo e o criticismo. São Paulo: Abril Cultural, 1973. (Os Pensadores).

SCHILLER, F. Cartas sobre a educação estética da humanidade. Introd. e notas Anatol Rosenfeld. São Paulo: EPU, 1991. 
Poesia ingênua e sentimental. Trad., apres. e notas M. Suzuki. São Paulo: Iluminuras, 1991.

. Sämtliche Werke. 5.ed. München: Artemis \& Winter, 1992. v.1.

SCHLEGEL, F. Kritische Schriften. München: Hanser, 1956. . Kritische Schriften und Fragmente (1798-1801). Padernborn: Schöningh, 1988. v.2.

. Conversa sobre a poesia e outros fragmentos. Trad. pref. e notas V.-P. Stirnimann. São Paulo: Iluminuras, 1994.

. Dialeto dos fragmentos. Trad., apres. e notas M. Suzuki. São Paulo: Iluminuras, 1997.

SCHOPENHAUER, A. Werke. Zürich: Haffman, 1988. v.I.

SHAKESPEARE, W. Hamlet, in deutscher Sprache. Trad. A. Schlegel, revista por F. Gundolf. Berlim: Bondi, 1921.

STEPHAN, H. von (Org.) Herders Philosophie: ausgewählte Denkmäler aus der Werdezeit der neuen deutschen Bildung. Leipzig: Meiner, 1936. (Philosophische Bibliotek, v.112).

STURM und Drang: Kritische Schriften. Heidelberg: Lambert Schneider, 1949.

SZONDI, P. Poetik und Geschichtsphilosophie I. Frankfurt am Main: Suhrkamp, 1974.

THEODOR, E. A língua alemã: desenvolvimento histórico e situação atual. São Paulo: Herder, 1963.

VIËTOR, K. Die Idee des Erhabenen in der deutschen Literatur. In: Geist und Form. Aufsätze zur deutschen Literaturgeschichte. Bern: Francke, 1952.

WINCKELMANN, J. J. Geschichte der Kunst des Altertums, vollständige Ausgabe. Wien: Phaidon, 1934.

. Edle Einfalt und stille Grösse. Zürich: Scientia, 1946.

. De la beleza en el arte clássico: seleccion de estudios y cartas. Trad. del alemán de J. A. Ortega y Medina. México: Universidad Nacional Autonoma de México, 1959.

. Reflexões sobre a arte antiga: estudo introdutório de Gerd A. Bornheim. Trad. H. Caro e L. Tochtrop. Porto Alegre: Movimento, 1975.

. Gedanken über die Nachahmung der griechischen Werke in der Malerei und Bildhauerkunst. Stuttgart: Reclam, 1991. 